\title{
Sosialisasi Pendirian “Bank Sampah” Bagi Peningkatan Pendapatan Dan Pemberdayaan Perempuan Di Margasari
}

\author{
Kusuma Wardany*1, Reni Permata Sari², Erni Mariana ${ }^{3}$ \\ ${ }^{123}$ Universitas Nahdlatul Ulama Lampung \\ ${ }^{1}$ Program Studi Teknik Informatika, ${ }^{2}$ Program Studi Statistika, ${ }^{3}$ Program Studi Teknologi Hasil Perikanan, \\ Universitas Nahdlatul Ulama Lampung, Lampung Timur \\ *e-mail: kusuma.wardany@ymail.com ${ }^{1}$,renipermatasari71@gmail.com² ${ }^{2}$ marianaerni558@gmail.com ${ }^{3}$
}

\begin{abstract}
The garbage bank has the function of channeling the waste obtained in accordance with the needs and providing an additional economy for the community. This service aims to make the mothers in Margasari Village know about the existence of a garbage bank, waste management techniques so that they are of economic value and are expected to increase the awareness and enthusiasm of mothers to process waste and preserve the environment. The realization of problem solving is carried out in a socialization program on how to establish and benefit the Waste Bank for increasing income and empowering women. The impact of empowering the garbage bank to customers can be said to be still lacking, this is evident from the average income earned by the community in the first three months of Rp. 10,786,00,-.The impact of empowerment for craftsmen and management can increase income with monthly income of around Rp. 900,000,-.
\end{abstract}

Keywords: Garbage Bank, Empowerment, Sosialization

\begin{abstract}
Abstrak
Bank sampah berfungsi menyalurkan sampah yang didapat sesuai dengan kebutuhan dan mermberikan tambahan ekonomi bagi masyarakat. Pengabdian ini bertujuan agar para ibu di Desa Margasari mengenal keberadaan bank sampah, teknik pengolahan sampah agar bernilai ekonomis dan diharapkan mampu meningkatkan kesadaran dan semangat para ibu untuk mengolah sampah dan melestarikan lingkungan. Realisasi pemecahan masalah dilakukan dalam acara sosialisasi cara pendirian dan manfaat Bank Sampah bagi peningkatan pendapatan dan pemberdayaan perempuan. Dampak pemberdayaan bank sampah terhadap nasabah bisa dikatakan masih kurang, hal ini telihat dari rata-rata pendapatan yang didapat oleh masyarakat dalam waktu tiga bulan pertama sebesar Rp. 10.786.000,-. Sedangkan dampak pemberdayaan untuk pengrajin dan pengurus dapat meningkatkan pendapatan dengan pendaptan perbulan kurang lebih sekitar Rp. 900.000,--
\end{abstract}

Kata Kunci: Bank Sampah, Pemberdayaan, Sosialisasi.

\section{PENDAHULUAN}

(Geografic, 2016) : Permasalahan sampah menjadi masalah yang belum terselesaikan dengan baik, khususnya di berbagai daerah di Indonesia. Jumlah sampah terus meningkat di setiap tahunnya. Kesadaran pemerintah dan masyarakat akan sampah harus digali agar terlepas dari permasalahan sampah . Menurut definisi World Health Organization (WHO) sampah adalah sesuatu yang tidak digunakan, tidak dipakai, dan tidak terjadi dengan sendirinya (Chandra, 2006). Perkembangan dan pertumbuhan penduduk yang pesat di daerah perkotaan mengakibatkan daerah pemukiman semakin luas dan padat. Peningkatan aktivitas manusai, lebih lanjut menyebabkan bertambahnya sampah. Faktor yang mempengaruhi jumlah sampah selain aktivitas penduduk ialah system pengelolaan sampah (Sulistyorini, 2005).

Sedangkan menurut undang-undang Republik Indonesia No. 18 Tahun 2018, sampah merupakan salah satu permasalahan lingkungan yang memerlukan penanganan khusus. Menurut Riset Greeneration, organisasi non pemerintah yang 10 tahun mengikuti isu sampah, satu orang di Indonesia rata-rata menghasilkan 700 kantong plastik per tahun. Di alam, kantong plastik yang 
tak terurai menjadi ancaman kehidupan dan ekosistem. Kondisi ini menjadi salah satu pemicu Indonesia dalam kondisi darurat sampah. Namun, tidak semua masyarakat menyadari kondisi ini.

Portal Direktorat Jenderal Cipta Karya Persampahan menyatakan bahwa rekapitulasi data persampahan Provinsi di Kabupaten Lampung Timur tertulis jumlah timbunan sampah per Orang/Hari mencapai 5,50 liter. Permasalah sampah juga terjadi di Empat dusun yakni Dusun 9, 10, 11 dan 12 yang ada di Desa Margasari, Kecamatan Labuhan Maringgai, tampak sangat kumuh karena banyak sampah yang berserakan di depan rumah warga dan comberan sekitarnya. Tidak sedikit sampah plastik yang dibuang berserakan di pinggir jalan, dan di dalam drainase sehingga menyumbat saluran air yang ada di depan rumah warga, dengan begitu air tidak lancar mengalir dan semakin lama sampah membusuk bersama lumpur menimbulkan bau tidak sedap. Menurut (Budiman, 2018) sepanjang mata memandang kawasan pantai di Desa Margasari tampak banyak sampah berceceran terutama sampah plastic, bahkan pada bibir atau tepi pantai tersebut, berbagai jenis sampah pun di dapati. Dari permasalahan tersebut warga dan pemerintah harus melakukan tindakan agar mengurangi masalah sampah.

Partisipasi masyarakat dalam pengelolaan sampah merupakan aspek yang terpenting untuk diperhatikan dalam sisitem pengelolaan sampah secara terpadu. Partisipasi masyarakat dalam suatu proses pembangunan terbagi atas 4 tahap, yaitu: a.) partisipasi pada tahap perencanaan, b.) partisipasi pada tahap pelaksanaan, c.) partisipasi pada tahap pemanfaatan hasil-hasil pembangunan dan d.) partisipasi dalam tahap pengawasan dan monitoring. Masyarakat senantiasa ikut partisipasi terhadap proses-proses pembangunan bila terdapat faktor-faktor yang mendukung, antara lain: kebutuhan, harapan, motivasi, ganjaran, kebutuhan sarana dan prasarana, dorongan moral, dan adanya kelembagaan baik informal maupun formal.

Keterlibatan masyarakat dalam pengelolaan sampah merupakan salah satu faktor teknis untuk menanggulangi persoalan sampah perkotaan atau lingkungan pemukiman dari tahun ke tahun yang semakin kompleks. Maka diperlukan upaya penerapan insentif bagi masyarakat yang mendukung upaya reduksi sampah melalui "Bank Sampah". Bank sampah ini fungsinya bukan melulu menumpuk sampah, namun bank ini menyalurkan sampah yang didapat sesuai dengan kebutuhan. Misal, sampah basah hasil rumah tangga yang terdiri dari sayuran, dikumpulkan untuk dijadikan pupuk kompos. Sampah kering berupa botol, kaleng dan kertas dipisah lagi. Biasanya sampah kering ini dijadikan barang kembali dari hasil daur ulang dan semua berupa kerajinan tangan. Misal, vas bunga dari kaleng bekas, tas dari rajutan sedotan atau pipet yang dianyam dengan benang dan jarum, bungkus rokok dibentuk asbak, dan masih banyak lagi. Semua pengolahan tersebut diserahkan pada masyarakat setempat. Dari masyarakat dan kembali ke masyarakat. Ternyata, bank bukan hanya bergerak dalam hal keuangan, tapi juga terhadap benda yang sudah dibuang. Ide untuk menanamkan bank sampah membuat image tentang pengumpulan barang bekas menjadi berbeda. Bank sampah justru bisa mendatangkan uang dari barang bekas bernama sampah, ditambah lagi memberikan tambahan ekonomi bagi masyarakat sekitar.

Ibu-ibu di desa Margasari sebagian besar berstatus ibu rumah tangga dengan melakukan pekerjaan sambilan sebagai buruh lepas, sehingga memiliki waktu kerja yang fleksibel. Untuk memenuhi kebutuhan sehari-hari, hingga pendidikan anak, para ibu berusaha membantu suami dengan bekerja harian sesuai kemampuan yang dimiliki. Sebagian besar mengaku tidak mampu untuk mengalokasikan penghasilannya untuk tabungan pendidikan. Kondisi ini membuat setiap tahun ajaran baru, banyak ibu-ibu di desa Margasari yang sibuk mencari pinjaman di lembaga kredit swasta atau pribadi yang tentu saja memberikan bunga yang cukup tinggi.

Desa Margasari memiliki pasar desa yang memiliki masalah pengelolaan sampah. Jika ibu-ibu mampu diberdayakan untuk mengelola sampah secara mandiri tentu akan memberikan dua manfaat dalam jangka panjang yaitu meningkatkan pendapatan hingga membersihkan lingkungan. Pengelolaan sampah plastik, koran, dan sampah organik bisa dimanfaatkan hingga bernilai ekonomis. Sampah organik bisa dipergunakan untuk pupuk organik yang dapat disalurkan kepada petani sehingga menekan biaya pembelian pupuk. Untuk bisa lebih mengenal 
sistem bank sampah tersebut, perlu diadakan sosialisasi kepada masyarakat di desa Margasari Lampung Timur, terutama para ibu yang sebagian besar ibu rumah tangga.

\section{METODE}

\subsection{Kerangka Pemecahan Masalah}

Masalah sampah yang dihadapi Desa Margasari, terutama akibat keberadaan dua pasar desa. Sampah yang menumpuk tidak hanya membuat lingkungan menjadi kotor, namun menimbulkan bau yang tidak sedap. Apalagi jika musim penghujan tiba, banyak sampah plastik yang menyumbat aliran sungai (tukad). Jika masyarakat memiliki kesadaran pribadi untuk bertanggung jawab memilah sampah rumah tangga yang dihasilkan, maka sampah akan dapat dikurangi dan memberikan tambahan nilai ekonomis bagi masyarakat itu sendiri. Begitu juga dengan kesadaran dan partisipasi pedagang di pasar desa untuk memilah sampah yang dihasilkan. Kondisi yang kini terjadi adalah sampah organik bercampur dengan sampah plastik lainnya. Bahkan sangat sering dijumpai hingga meluber ke jalan. Sampah organik sebenarnya bisa dimanfaatkan sebagai pakan ternak atau pupuk kompos. Sedangkan sampah plastik bisa dijual kembali. Menumbuhkan kesadaran warga bisa dilakukan melalui sosialisasi sistem bank sampah sebagai tindakan nyata untuk menanggulangi sampah menjadi bernilai ekonomis sekaligus menunjang ketersediaan pupuk kompos bagi pertanian organik di Margasari pada khususnya.

\subsection{Realisasi Pemecahan Masalah}

Realisasi pemecahan masalah dilakukan dalam acara sosialisasi cara pendirian dan manfaat Bank Sampah bagi peningkatan pendapatan dan pemberdayaan perempuan . Kegiatan tersebut dilakukan pada hari Selasa, 4 February 2020 . Sosialisasi dan kunjungan lapangan bank sampah ini dilakukan di Desa Margasari, Lampung Timur.

\subsection{Khalayak Sasaran}

Peserta sosialisai terdiri dari 10 orang, dari unsur ibu rumah tangga yang terlibat langsung dalam pengelolaan sampah rumah tangga dan usaha. Acara diawali dengan perkenalan anggota kelompok pengabdian masyarakat Dosen Universitas Nahdlatul Ulama Lampung, pemaparan materi ceramah, penjelasan manfaat pengelolaan sampah organik dan anorganik, penjelasan cara pengelolaan sampah organik dan anorganik, penjelasan tentang Bank Sampah hingga tempat penimbangan sampah organik dan anorganik yang diterima. Setelah kunjungan lapangan, acara dilanjutkan dengan diskusi dan makan siang bersama.

\subsection{Metode yang Digunakan}

Metode yang cocok digunakan dalam melaksanakan kegiatan tersebut agar lebih efektif dalam mencapai tujuan adalah ceramah sosialisasi manfaat bank sampah dan kunjungan lapangan mengenai bagaimana sistem bank sampah tersebut terbentuk.

\subsection{Kegiatan Dan Jadwal}

Tabel 1. Kegiatan

\begin{tabular}{lccccc}
\hline \multicolumn{1}{c}{ Kegiatan } & 15Jan & 25 Jan & 28 Jan & 4 Feb & 6 Feb \\
\hline $\begin{array}{l}\text { Penyusunan proposal } \\
\text { Persiapan ceramah }\end{array}$ & $\sqrt{ }$ & $\sqrt{ }$ & & & \\
Survey lapangan & & & $\sqrt{ }$ & & \\
Ceramah & & & $\sqrt{ }$ & \\
Penyelesaian laporan & & & & $\sqrt{ }$ \\
\hline
\end{tabular}




\section{HASIL DAN PEMBAHASAN}

Mekanisme Pengelolaan sampah: Mekanisme pengelolaan sampah di Bank Sampah Margasari merupakan strategi yang didesain dalam upaya mengintegrasikan biaya lingkungan ke dalam seluruh proses produksi suatu barang sampai produk itu tidak dapat dipakai lagi sehingga biaya lingkungan menjadi bagian dari komponen harga pasar produk tersebut. Dengan pegelolaan ini diharapkan akan mengurangi keberadaan sampah tidak terpakai yang ada di lingkungan desa Margasari semaksimal mungkin.

Adapun mekanisme pengelolaan sampah di Bank Sampah Margasari sebagai berikut :

1. Nasabah mempunyai sampah rumah tangga yang akan di tabung di bank Sampah Margasari.

2. Nasabah melakukan Pemilahan dan pembersihan sampah yang nantinya akan dibawa ke Bank Sampah Margasari. pemilihan dilakukan dengan cara memisahkan sampah berdasarkan jenisnya. Karena setiap sampah memiliki harga yang berbeda-beda.

3. Sampah yang telah di pilah ditimbang oleh petugas bank sampah Margasari berdasarkan jenisnya. setiap sampah memiliki harga yang berbeda berdasarkan jenisnya.

4. Hasil timbangan sampah di catat dalam buku milik petugas bank sampah Margasari dan buku tabungan milik nasabah yang didalamnya berupa pencatatan jumlah uang yang didapat oleh nasabah.

5. Sampah dari nasabah di simpan dalam gudang penyimpanan Bank Sampah Margasari.

6. Kumpulan sampah dari nasabah yang terkumpul akan diambil untuk didaur ulang oleh bank sampah sesuai kebutuhan. Sampah yang tidak memungkinkan untuk didaur ulang akan di jual ke pengepul.

7. Hasil daur ulang bank sampah di pasarkan dan dijual untuk umum. Sehingga sampah kembali digunakan oleh masyarakat.

\subsection{Harga sampah}

Bank sampah Margasari menerima hampir semua sampah rumah tangga. Hal ini dikarenakan bank Sampah Margasari ingin tidak ada sampah yang dibuang oleh masyarakat. adapun jenis sampah dan harganya sebagai berikut :

Table 2. Harga sampah di bank sampah

\begin{tabular}{ccc}
\hline No & Jenis Sampah & Harga/Rp \\
\hline 1 & Kardus & $1500 / \mathrm{Kg}$ \\
2 & HVS Putih (SWL) & $1200 / \mathrm{Kg}$ \\
3 & CD & $1000 / \mathrm{Kg}$ \\
4 & Sak Semen & $1600 / \mathrm{Kg}$ \\
5 & Marga & $850 / \mathrm{Kg}$ \\
6 & Atom Campur & $1700 / \mathrm{Kg}$ \\
7 & PVC, Pralon & $900 / \mathrm{Kg}$ \\
8 & Atom Hitam & $700 / \mathrm{Kg}$ \\
9 & Atom keras (mainan anak) & $300 / \mathrm{Kg}$ \\
10 & Botol Susu,Putihan,HDPE & $2500 / \mathrm{Kg}$ \\
11 & PS, Kaset CD & $2750 / \mathrm{Kg}$ \\
\hline
\end{tabular}




$\begin{array}{lcc}12 & \text { Gelas Putih (plastik) } & 3000 / \mathrm{Kg} \\ 13 & \text { Gelas Warna (plastik) } & 2000 / \mathrm{Kg} \\ 14 & \text { Gelas Campur (plastik) } & 2300 / \mathrm{Kg} \\ 15 & \text { Botol Plastik Bening } & 2700 / \mathrm{Kg} \\ 16 & \text { Botol Plastik Warna } & 1800 / \mathrm{Kg} \\ 17 & \text { Botol Plastik Campur } & 2000 / \mathrm{Kg} \\ 18 & \text { Plastik Bening Polos } & 2500 / \mathrm{Kg} \\ 19 & \text { Plastik Bening Sablon } & 800 / \mathrm{Kg} \\ 20 & \text { Plastik Kresek } & 350 / \mathrm{Kg} \\ 21 & \text { Plastik minuman sachet } & 2000 / 100 \mathrm{bks} \\ 22 & \text { Botol Kecap } & 600 / \mathrm{satuan} \\ 23 & \text { Botol bening } & 500 / \mathrm{satuan} \\ 24 & \text { Botol warna/coklat } & 250 / \mathrm{satuan} \\ 25 & \text { Botol Hijau } & 1500 / \mathrm{satuan} \\ 26 & \text { Beling campur } & 1500 / \mathrm{satuan} \\ 27 & \text { Besi A } & 3000 / \mathrm{Kg} \\ 28 & \text { Besi B } & 2000 / \mathrm{Kg} \\ 29 & \text { Kaleng } & 1300 / \mathrm{Kg} \\ 30 & \text { Seng } & 800 / \mathrm{Kg} \\ 31 & \text { Alumunium } & 8000 / \mathrm{Kg} \\ 32 & \text { Ban } & 400 / \mathrm{Kg} \\ 33 & \text { Sandal } & 400 / \mathrm{Kg} \\ & \text { Tas } & 100 / \mathrm{Kg} \\ & & \end{array}$

Sumber : data bank sampah

Harga sampah yang ada di Bank Sampah dapat setiap saat berubah. Ini dikarenakan sampah pada harga pasaran tidak statis. Naik turunnya harga biasannya mengikuti harga pengepul pada umumnya. Namun dalam perubahan harga nasabah tersebut tetap akan di beritahu.

Untuk jenis sampah organik Bank Sampah Margasari tidak membeli sampah tersebut. Bank Sampah Margasari mengajak serta menawarkan kepada masyarakat sebuah kerjasama untuk mengelola sampah organik bersama-sama. Kerjasama tersebut berupa pihak bank sampah menyediakan kantong-kantong untuk pengomposan warga yang memang bersedia untuk melakukan pengomposan di persilahkan mengisi tong-tong tersebut. Hasil pengomposan tersebut 
jika sudah benar-benar menjadi kompos dapat dijual atau digunakan dengan pembangian hasil $60 \%$ untuk warga yang mengisi serta merawat tong dan $40 \%$ untuk bank sampah. Tapi pada kenyataannya hampir tidak ada (bahkan selain pengurus memang tidak ada) yang mau mengisi tong-tong tersebut. Warga malah menawarkan sampah-sampah organik tong-tong kepada pihak bank sampah untuk diambil tanpa meminta bayaran layaknya sampah non organik. Hal ini dikarenakan untuk mengisi tong-tong tersebut diperlukan sampah organik yang cukup banyak. Namun warga hanya sedikit menghasilkan sampah organik sehingga tidak memenuhi tong-tong yang telah disediakan.

Menurut manajer bank sampah, bagian sampah terbesar di Desa Margasari adalah sebanyak 80 persen (46 ton/hari) merupakan sampah organik yang dapat diproses menjadi kompos (10 ton/hari). Kompos ini diutamakan dijual untuk petani memperbaiki tanah yang rusak dan asam akibat pengunaan pupuk kimia dan pestisida yang berlebih. Penggunaan lainnya adalah untuk perkebunan. Sejumlah kecil sampah (5 persen) adalah sampah yang dapat didaur ulang (plastic, kaca, dll) yang dijual untuk diolah kembali. Hanya sekitar 15 persen sampah yang diangkut adalah residu yang dibuang ke TPA yang berlokasi di sebelah fasilitas. Pengurangan sampah 80 persen menjadi 5 persen residu dapat memperpanjang usia TPA hingga 10 kali lebih lama.

Nasabah bank sampah yang dibentuk diikuti oleh sebagian besar kaum perempuan di Desa Margasari. Sampah plastik, kertas, besi dan metal yang disetor anggota dihargai sesuai dengan jenis sampah. Seperti Koran bekas dihargai Rp 600,-/kg, kemasan gelas plastik dihargai Rp 2500/kg. Semua sampah yang disetor dicatat dalam buku tabungan. Nasabah baru berhak menerima uang setelah enam bulan menabung sampah.

\subsection{Peran Bank Sampah Margasari Dalam Pemberdayaan Masyarakat}

Peran Bank Sampah Margasari Dalam Pemberdayaan Masyarakat dapat terlihat pada dampak yang dihasilkan. Ada dua dampak menojol yang dihasilkan oleh Bank Sampah Margasari terhadap masyarakat yaitu :

\section{Dampak ekonomi masyarakat}

Bank Sampah Margasari merupakan sebuah kelompok masyarakat yang bertujuan untuk memberdayakan serta meningkatkan perekonomian masyarakat dengan cara memanfaatkan sampah sebagai salah satu sumber pendapatan. Selain sebagai sumber pedapatan dengan adaanya Bank Sampah Margasari dapat mengurangi masalah sampah yang ada di desa Margasari. Menurut Iswanto (2006), hampir semua sampah dapat dimanfaatkan atau bernilai ekonomis setelah dilakukan pemilahan (dapat dijual). Jika sampah dipilahkan sejak dari rumah tangga (penghasil sampah), maka yang dihasilkan bukan lagi berupa sampah lagi, tetapi berupa barangbarang yang bernilai ekonomi..

Pemberdayaan yang dilakukan bank sampah terhadap masyarakat hasilnya adalah tentang bagaimana bank sampah dapat meningkatkan pendapatan yang ada di masyarakat sehingga dapat memenuhi kebutuhan mereka. Masyarakat yang menjadi anggota Bank Sampah telah mendapatkan dampak berupa peningkatan pendapatan. Dampak yang dihasilkan setiap anggota berbeda, tergantung partisipasi yang dia lakukan anggota sendiri terbagi menjadi yaitu peran bank sampah terhadap peningkatan pendapatan nasabah bisa dikatakan masih kurang, hal ini dikarenakan sampah yang ditabung merupakan sampah rumah tangga milik pribadi dalam waktu satu tahun. Nasabah yang hasil tabungannya paling banyak hanya berjumlah Rp536.800 . Sedangkan untuk hasil tabungan pada bank yang tabungannya paling sedikit sebesar Rp. 40.000. Dampak pemberdayaan bank sampah terhadap nasabah bisa dikatakan masih kurang, hal ini telihat dari rata-rata pendapatan yang didapat oleh masyarakat dalam waktu tiga bulan pertama sebesar Rp. 10.786.000,-. (Wawancara Nasabah). 
Peran bank sampah terhadap peningkatan pendapatan pengrajin bisa dikatakan cukup berhasil hal ini terlihat dari upah atau balas jasa yang ditawarkan oleh bank sampah terhadap para pengrajin untuk rincian upah pengrajin sebagai berikut :

1) Cuci bungkus kopi dan sejenisnya : $5000 / \mathrm{kg}$

2) Cuci bungkus minyak dan sejenisnya : $600 / \mathrm{kg}$

3) Cacahan : $10.000 / \mathrm{kg}$

4) Jahit harian : 25.000/ hari

5) Borongan : $1.000 \mathrm{~s} / \mathrm{d} 10.000$ tergantung kreasi yang di buat

6) Nganyam $3.500 / 100 \mathrm{bks}$

7) Jahit anyaman : 2 000/100 bks

Dari upah tersebut pengrajin bisa mendapatkan peghasilan 500.000-900.000 rupiah perbulan, namun jika ada pesanan yang banyak dari pembeli pengrajin bisa mendapatkan penghasilan 1.000 .000 perbulan.

Peran bank sampah terhadap peningkatan pendapatan pengurus terlihat cukup berhasil. Pengurus tidak mengambil keuntungan dari tabungan sampah. Namun pengurus mengambil keuntungan dari hasil penjualan barang kreasi. Hasilnya ini nantinya akan di bagi kesemua pengurus. Ini sejalan dengan pengabdian yang telah dilakukan oleh (Lestari, 2018)bahwa kegiatan pengelolaan sampah memberikan dampak yang positif, sebab dapat dijadikan pemasukan yang dapat dipergunakan untuk biaya pendidikan.

Dengan adanya bank sampah dapat membuat sebuah lapangan pekerjaan baru. Ini sejalan dengan (Saputro, 2015) bahwa manajemen Bank Sampah sudah cukup baik memberikan dampak pada social ekonomi masyarakat meskipun masih ada beberapa masalah teknis dilapangan. Selain itu Ibu-ibu rumah tangga yang kesehariannya masih ada waktu luang yang cukup banyak dapat menjadikan bank sampah sebagai salah satu sumber peningkatan pendapatan. Tidak hanya ibuibu, pelajarpun bisa menjadikan bank sampah sebagai penambah uang jajan dan sarana edukasi tentang pengelolaan sampah yang baik dan dapat bernial ekonomis. Menurut (Sekarningrum, 2017) bahwa pihak berwenang, pemerintah daerah dan institusi/organisasi social harus memberikan program yang kontiny, agar masyarakt local memiliki kesadaran tentang pentingnya memiliki kebiasaan yang bail dalam pengelolaan sampah secara efektif dan bijaksana. Dengan adalanya sosialiasi dan pelatihan cara pendirian bank sampah ini berdampak terjadinya perubahan perilaki dan cara pandang masyarakat yang menjadi peserta pelatihan untuk mengelola sampah secara komunal.

\subsection{Identifikasi Masalah Sosialisasi Pendirian Bank Sampah di Margasari Lampung Timur}

Pada acara sosialisasi dan kunjungan lapangan tersebut, teridentifikasi beberapa permasalahan yang dihadapi untuk mendirikan bank sampah di Desa Margasari . Antara lain :

1. Masih banyak ibu-ibu yang enggan untuk melakukan pemilahan sampah. Baik karena alasan waktu, malas, dan menganggap nilai ekonomis sampah sangat rendah. Mereka lebih memilih untuk menyerahkan kepada pemulung untuk ditukarkan dengan perabot plastik yang dibawa pemulung sebagai barter.

2. Masih minimnya kesadaran para pedagang di pasar desa untuk melakukan pemilahan sampah organik dan an-organik. Sehingga pengelola pasar harus mengeluarkan dana hingga Rp 1 juta setiap bulan.

3. Potensi ibu-ibu yang tergabung dalam PKK belum dilakukan pendekatan secara formal oleh lembaga kemasyarakatan yang ada. Rencana pendirian bank sampah masih sebatas tatanan wacana di kalangan pengurus. Padahal peserta sosialisasi sudah menyatakan kesediaan 
untuk menghimpun diri membentuk kelompok bank sampah.

4. Ketersediaan sampah organik sebenarnya bisa dimanfaatkan menjadi pupuk organik yang sangat diperlukan kalangan petani yang menerapkan sistem pertanian organik. Beberapa anggota peserta sosialisasi telah membuktikan manfaat pupuk organik dari sampah organik yang disalurkan. Padahal jika dilakukan secara berkelompok pasti akan menghasilkan pupuk yang lebih banyak.

5. Dari segi potensi, ibu-ibu di Desa Margasari Lampung Timur sebenarnya mampu untuk membentuk kelompok bank sampah. Hanya menunggu para pimpinan pemuka masyarakat untuk membuatkan sistem bank sampah, sekaligus menyediakan fasilitas yang diperlukan. Kualitas SDM dan militansi anggota tidak menjadi masalah, apalagi jika digerakkan pengurus PKK. Keberadaan banyak minimarket dan wisata di Singapadu sebenarnya bisa diajak bekerjasama dalam pemilahan sampah agar bernilai ekonomis.

\section{KESIMPULAN}

Dampak pemberdayaan bank sampah terhadap nasabah bisa dikatakan masih kurang, hal ini telihat dari rata-rata pendapatan yang didapat oleh masyarakat dalam waktu tiga bulan pertama sebesar Rp. 10.786.000, -. Sedangkan dampak pemberdayaan untuk pengrajin dan pengurus dapat meningkatkan pendapatan dengan pendaptan perbulan kurang lebih sekitar 900.000 rupiah.

Selain berperan dalam pengerak ekonomi masyarakat, bank sampah juga berperan dalam sosial. Adapun dampak sosial masyarakat yang timbul akibat dari adanya Bank sampah Marga Sari adalah :

a. Terciptanya lingkungan bersih

b. Meningkatnya kualitas kesehatan bagi masyarakat

c. Saling membantu sesama anggota Bank Sampah Margasari

\section{DAFTAR PUSTAKA}

Budiman, B. (2018). Penanggulangan Sampah di PesisirLampung Timur. Lampung Timur: https://www.antaranews.com/berita/774339/penanggulangan-sampah-di-pesisir-

lampung-timur.

Chandra, Budiman. 2006. PEngantar Kesehatan Lingkungan. Jakarta: EGC

Geografic, N. (2016). Indonesia Darurat Sampah . Indonesia darurat sampah. http://nationalgeografic.co.id/berita/2016/01/indonesia-darurat-sampah. diakses pada tanggal 31 januari 2020

Iswanto. (2006). Pengelolaan Sampah Rumah Tangga Secara Mandiri dan Produktif Berbasis Masyarakat: Kampung Sukunan, Banyuraden, Gamping, Sleman, D.I.Yogyakarta, Paguyuban Sukunan Bersemi, Yogyakarta

Lestari, S. M. (2018). Peningkatan keterampilan mahasiswa dalam pengelolaan sampah organic untuk mewujudkan green campus di Universitas Lancang Kuning DINAMISIA. Jurnal Pengabdian Kepada Masyarakat. [P-ISSN 2614-7424| E-ISSn 2614-8927] Hlm. 193-196.

Portal Direktorat Jenderal Cipta Karya Persampahan. Rekapitulasi Data Persampahan Provinsi. http://ciptakarya.pu.go.id/plp/simpersampahan/baseline/rosampahdataproplist.php?id= 3300\&tabid=dataumum diakses pada tanggal 31 Januari 2020

Saputro, Y. E. (2015). Pengelolaan Sampah Berbasis Masyarakat Melalui Bank Sampah.

Sekarningrum, B. (2017). Pengembangan Bank Sampah Pada Masyarakat di Bantaran Sungai Cikapundung. Universitas Padjajaran. Jurnal Pengabdian Masyarakat. [ISSN:1410-5675]. Hal.292-298 
Sulistyorini, L. 2005. Pengelolaan Sampah dengan Menjadikannya Kompos.

journal.unair.ac.id/filerPDF/KESLING-2-1-08.pdf

Undang-Undang Republik Indonesia Nomor 18 Tahun 2008 Tentang Pengelolaan Sampah. 